\title{
7 Determinants of the spatial differentiation of labor markets in Poland and Ukraine
}

\author{
Pawet Dykas, Tomasz Misiak and \\ Tomasz Tokarski
}

\subsection{Introduction}

The labor market is one of the integral elements of the modern economy. Its characteristic features are, a high heterogeneity, and high sensitivity to the economic cycle or political turmoil and migration issues, amongst others. In spatial terms, it is characterized by a large diversity of basic variables defining the situations on the labor market. The spatial diversity of local or regional labor markets is not only a feature of countries undergoing systemic transformation but also applies to developing and highly developed countries (Bradley and Taylor 1997; Egger et al. 2005; Arntz and Wilke 2009; Marelli et al. 2012).

The most important variables determining the situation and prospects of the labor market are most often labor productivity, the level of wages or unemployment rate and employment. The above-mentioned macroeconomic categories are shaped by many determinants. The authors' attempt to endogenize selected variables of the labor market such as increases in unemployment rates or gross real wages by ascertaining the basic determinants resulting from the Solow 1979 efficiency wage mode, and the neoclassical growth model of Solow (1956) and its generalizations or directly from the definition of the unemployment rate. The Solow-Swan model is an economic formula of long-run economic growth set within the framework of neoclassical economics. It attempts to explain long-run economic growth by looking at capital accumulation, labor or population growth and increases in productivity, which are commonly referred to as technological progress. Determinants resulting from theoretical models are then verified empirically using the econometric methods for panel data.

The main purpose of the analyses carried out in this chapter is to compare the spatial diversity of regional labor markets in Poland and Ukraine in the first two decades of the 21st century. These analyses relate to changes in the number of people employed, the trajectory of unemployment rates, diversity and dynamics of labor productivity (measured by GDP per employee), variability of wages and regional unemployment rates, and an estimation of the equation parameters taking into account basic determinants of real wages and any crease in unemployment rates. 


\section{8}

Pawet Dykas et al.

\subsection{The labor market in Poland and Ukraine in the XXI century}

The basic factor that determined the volume of employment and unemployment in Poland in 2001-2018 was the GDP dynamics. In prosperous times, the number of people employed usually increased, and the number of unemployed and the unemployment rate fell.

Figures 7.1 and 7.2 present the dynamics of GDP, the number of employed persons and the trajectory of the unemployment rate in Poland. ${ }^{1}$ The following conclusions can be drawn from these figures.

In the years 2001-2002, as the result of a cooling down of the economy (and a quite restrictive fiscal policy of the government) at the end of the 20th century and due to a restrictive monetary policy of the National Bank of Poland (Narodowy Bank Polski), the growth rate of Polish GDP was low (in 2002 the GDP growth rate was $2.0 \%$, in 2003, 3.6\%). This, with the rapidly increasing labor productivity $5.2 \%$ in 2002 and $4.8 \%$ in 2003), translated into a decline in labor demand, a decrease in employment and an increase in the unemployment rate. In the years 2001-2003 the number of employed in Poland fell by $4.1 \%$ (with an increase of GDP by $5.7 \%$ ), while the unemployment rate increased from 18.3 to $19.8 \%$. This can be explained by the fact that with high labor productivity growth rates and much lower GDP growth rates (and product market demand), employers reduced employment. The unemployment rate in Poland (next to Spain and Slovakia) in 2003 was among the highest in central and western Europe.

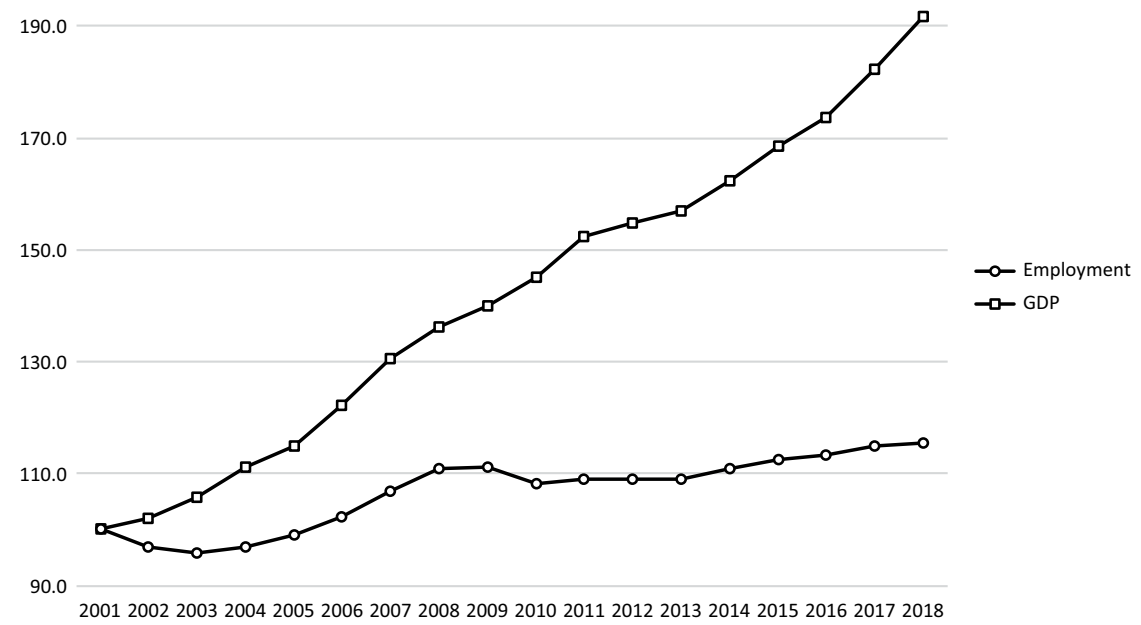

Figure 7.1 Dynamics of GDP and employment in Poland in the 21st century $(2001=100)$

Source: Our own estimates based on https://w3.unece.org/ reading data: 2019-12-30). 


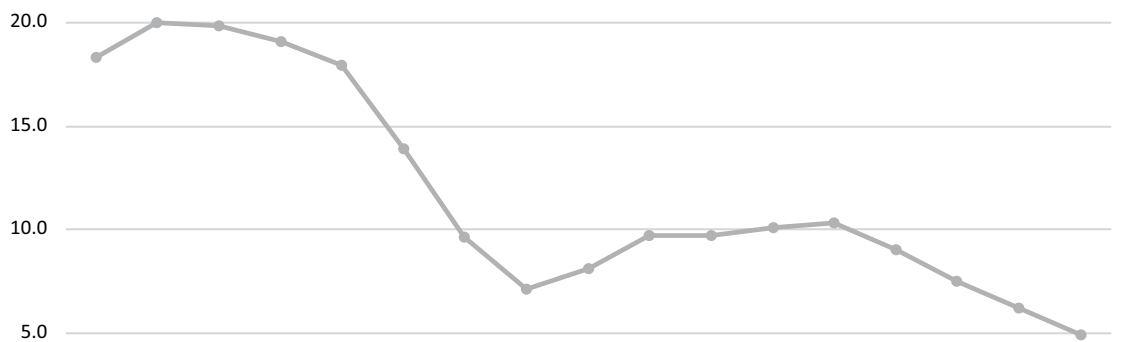

0.0

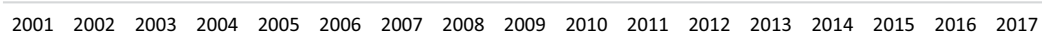

Figure 7.2 Unemployment rates in Poland in the 21th century (\%).

Source: Our own estimates based on https://w3.unece.org/ reading data: 2019-12-30).

Poland's accession to the EU in 2004 combined with a period of prosperity in the global economy led to a significant acceleration of economic growth in Poland. The average annual GDP growth rate in 2004-2007 increased to $5.5 \%$. This, in turn, led to an increase in labor demand, an increase in employment and a decrease in unemployment (in 2003-2008 the unemployment rate in Poland fell from 19.8 to $7.1 \%$, while the number of employed rose at this time by $15.6 \%$, i.e., by about 2.1 million people).

The global financial crisis translated into a significant slowdown in economic growth in Poland (in 2007-2013 the average annual GDP growth rate fell to a level of 3.1\%). This caused a reduction in employment and an increase in unemployment, which lasted until 2013 (when the unemployment rate was $10.3 \%$ ).

In the years 2013-2018, largely due to a favorable economic situation in the global economy, the GDP growth rate in Poland increased to $4.1 \%$, which led to a cumulative increase in the number of employed in Poland by $22.0 \%$ (approx. 0.9 million persons) and a drop in the unemployment rate to $4.6 \%$ in 2017. This rate is currently one of the lowest in the EU.

The situation was different in Ukraine. Ukraine in the 1990s, due to strong links with the other economies of the former Soviet Union and a failure to undertake significant market and structural reforms, underwent a deep recession. Ukraine's GDP in 1999 accounted for only $41.0 \%$ of the value of this variable from 1990 (by comparison, in Poland the GDP increased by $37.6 \%$ during this period). ${ }^{2}$ The first signs of economic recovery in Ukraine, apparently paradoxically, were the result of the Russian financial crisis of 1998. This crisis led to a strong depreciation of the Russian ruble and the Ukrainian UAH (the average annual USD/UAH exchange rate in 1997 was 
1.86; in 1998, 2.45; in 1999, 4.13; and in 2000, 5.44). ${ }^{3}$ The depreciation of the UAH resulted in a surge in prices of products imported into Ukraine, when counted in UAH. This, in turn, caused that part of the demand of Ukrainian business entities (in particular households and enterprises) to shift from foreign to domestic products. This move led to the creation of a Keynesian multiplier mechanism, which revived the economy.

In the years 2001-2007, the average annual growth rate of the Ukrainian GDP was $7.5 \%$ (a decrease in the high growth rate in this period took place only in 2005 , which was a direct result of the political and social crisis following the Orange Revolution at the turn of 2004/2005). The rapid GDP growth in Ukraine in 2001-2007 led to an increase in the number of employed in 2008 by $5.0 \%$ compared to 2001 (i.e., by about one million people) and a decrease in the unemployment rate from 10.9 to $6.4 \%$ (Figs. 7.3 and 7.4).

The Russian-Ukrainian gas conflict $2008-2009^{4}$ led to a one-year recession (a 15.1\% decrease in GDP in 2009), which translated into a decrease in the number of employed by $3.7 \%$ (around 0.8 million people) and an increase in the unemployment rate from 6.4 to $8.8 \%$.

In the years 2010-2013 (i.e., between the Russian-Ukrainian gas conflict and the Euromaidan), the Ukrainian GDP began to increase again (cumulative growth was then $6 \%$ ), which translated into a $1 \%$ increase in the number of people employed combined with a decrease in unemployment by $1.5 \%$ points.

The direct consequences of the Euro-Maidan at the turn of 2013 and 2014 were the Russian annexation of the Crimean Peninsula (i.e., the Autonomous Republic of Crimea with Sevastopol) in the first half of 2014, and a social

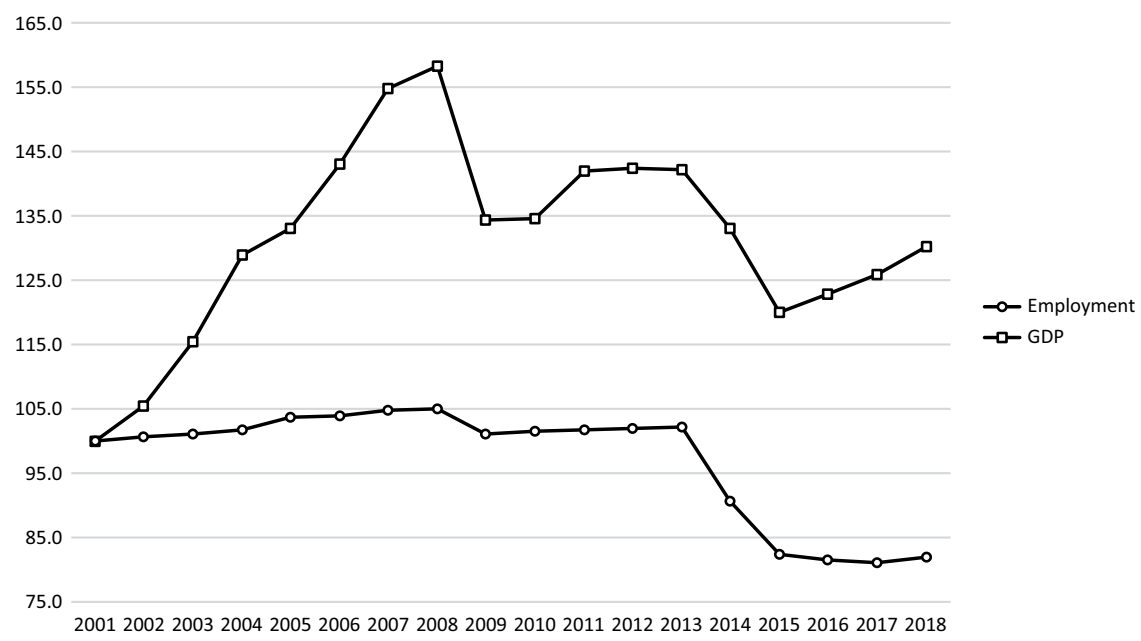

Figure 7.3 Dynamics of GDP and employment in Ukraine in the 21st century $(2001=100)$.

Source: Our own estimates based on https://w3.unece.org/ reading data: 2019-12-30). 


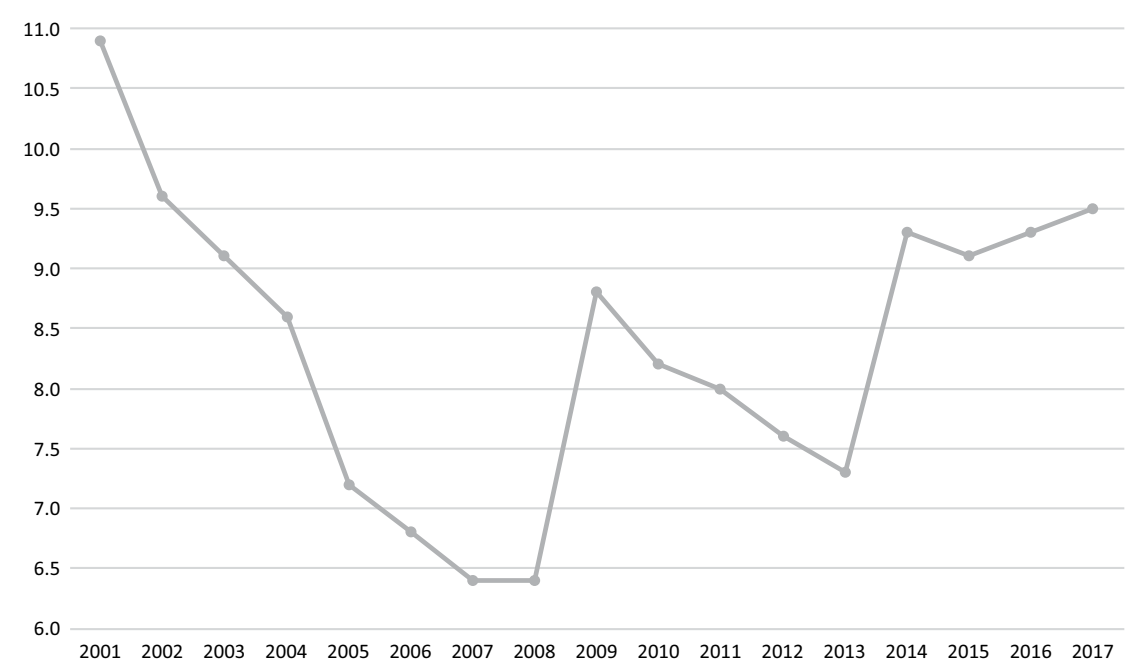

Figure 7.4 Unemployment rates in Ukraine in the 21th century (\%).

Source: Our own estimates based on https://w3.unece.org/ reading data: 2019-12-30).

and political crisis, which led to open warfare with the pro-Russian separatists in the Donbas (Donetsk and Luhansk oblasts). As a result, Ukraine has again experienced a deep economic recession. In 2014, the Ukrainian GDP fell by $6.6 \%$, while the number of people employed decreased by $11.4 \%$. This reduction in the number of people employed resulted from the annexation of Crimea, fighting in the Donbas and the economic recession. ${ }^{5}$ The unemployment rate increased abruptly by $2 \%$ points (to $9.3 \%$ ). After 2014 , despite an increase in the GDP in 2015-2018, the number of employed has stabilized at around 16.3-16.4 million people, and the unemployment rate at around $9.3-9.5 \%$.

\subsection{Differentiation in labor productivity, wages and unemployment rates}

Map 7.1 illustrates the spatial diversity of labor productivity in Poland on average for 2004-2016. In contrast, Figure 7.5 shows the trajectories of this variable in groups of voivodeships. The following map and graph show what ensued (see also Tokarski 2005a, b, 2008; Mroczek, Tokarski 2013; Trojak, Tokarski 2013; Trojak 2015; Mroczek et al. 2014 or Filipowicz 2017, 2019):

\subsubsection{Differentiation in labor productivity, wages and unemployment rates in Poland}

- As in the case of GDP per capita, the Mazowieckie Voivodeship also had by far the highest level of labor productivity (PLN 128.8 thousand). 
$[58.567: 68.707](3)$ $[69.441: 73.391](3)$

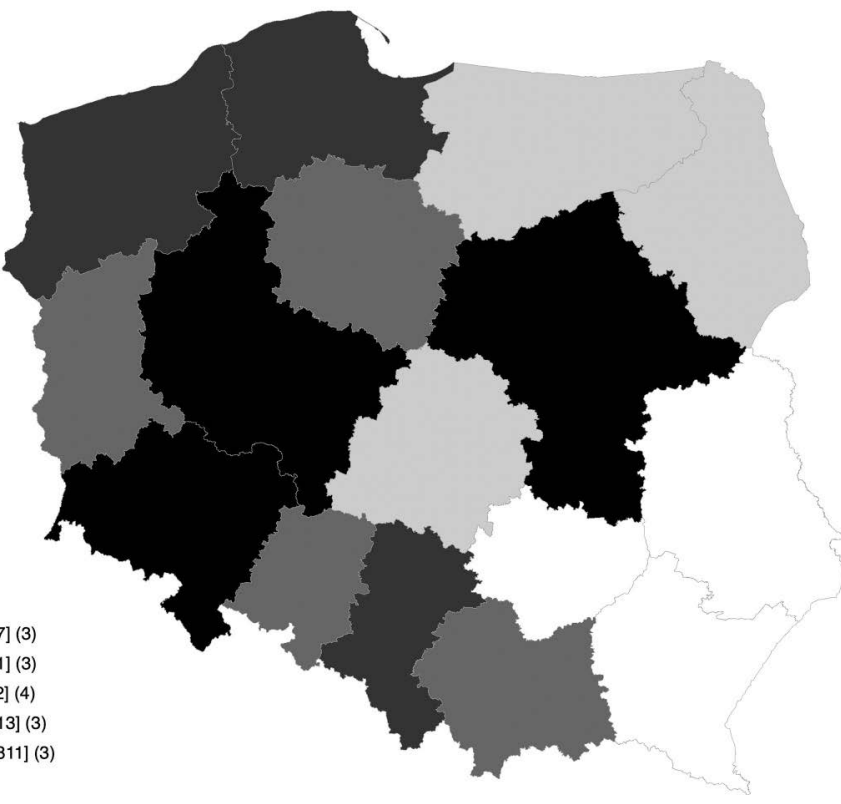

Map 7.1 Labor productivity in Polish voivodeships in 2004-2016 (1,000 PLN, according to 2015 prices).

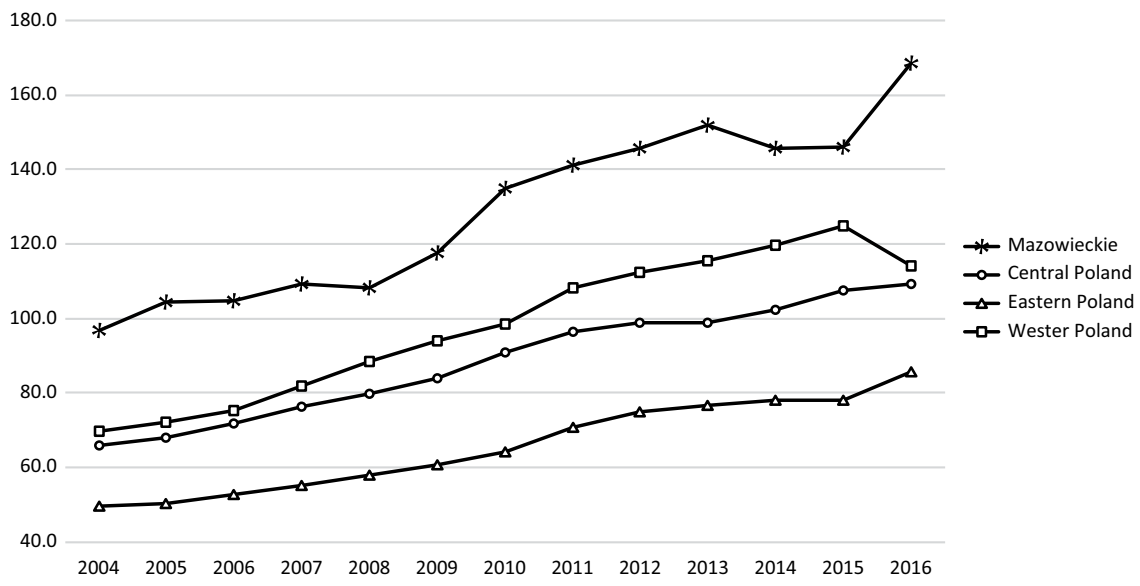

Figure 7.5 Labor productivity in Polish voivodeships groups in 2004-2016 (1,000 PLN, according to 2015 prices).

Source: Our own estimates based on: https://bdl.stat.gov.pl/BDL/start (access: 2019-12-30). 
In addition, in the Dolnośląskie (107.2 thousand PLN), Wielkopolskie (101.4 thousand PLN) and Śląskie (100.5 thousand PLN) voivodeships, the value of the macroeconomic variable considered here exceeded 100 thousand PLN. In the Pomorskie (PLN 98.1 thousand) and Zachodniopomorskie (PLN 95.7 thousand) voivodeships, the average production per employee was higher than 90 thousand PLN.

- The group of voivodeships with low labor productivity was composed of the following voivodeships: Lubuskie (78.1 thousand PLN), WarmińskoMazurskie (73.4 thousand PLN) and Łódzkie (72.3 thousand PLN). The lowest value of this feature was recorded in three voivodeships of eastern Poland: the Podlaskie (69.4 thousand PLN), Świętokrzyskie (63.7 thousand PLN) and Lubelskie (58.6 thousand PLN).

- Such spatial diversity of the macroeconomic variable analyzed for Poland was mainly due to the spatial differentiation of capital-labor ratio and (to a lesser extent) the diversity of gravity effects (see Tokarski 2005b; Mroczek, Tokarski 2013; Trojak, Tokarski 2013; Trojak 2015; Mroczek et al. 2014 or Filipowicz 2017, 2019).

- Between 2004 and 2016, an increase in labor productivity was recorded in all voivodeships. The fastest-growing value of this macroeconomic variable grew in the following voivodeships: Lubelskie (a cumulative growth equal to $94.7 \%$, an average annual growth of $5.7 \%$ ), then in Łódzkie (92.3\% and 5.6\%, respectively), Małopolskie (81.3\%, 5.1\%), Mazowieckie $(74.4 \%, 4.7 \%)$ and Podkarpackie $(72.4 \%, 4.6 \%)$. The slowest increase in labor productivity was in the Śląskie $(55.0 \%, 3.7 \%)$, Zachodniopomorskie $(51.1 \%, 3.5 \%)$, Pomorskie $(42.3 \%, 3.0 \%)$ and Opolskie $(41.9 \%, 3.0 \%)$ voivodeships.

- Labor productivity in the Mazowieckie Voivodeship was much higher than the value of this macroeconomic variable in other groups of voivodeships. It grew from 96.7 thousand PLN in 2004 to 168.5 thousand PLN in 2016. In the remaining groups of voivodeships, production per employee increased from a level of 69.8 thousand PLN in 2004 to 124.8 thousand PLN in 2015, it later fell to a level of 114.0 thousand in 2016 PLN in western Poland, ${ }^{6}$ in central Poland it grew from 65.8 thousand PLN in 2004 to 109.4 thousand PLN in 2016, and in the voivodeships of eastern Poland it increased from 49.4 thousand PLN up to 85.7 thousand PLN.

- It is also worth noting that the level of labor productivity in the voivodeships of eastern Poland in 2017 was significantly lower than the value of this variable in the Mazowieckie Voivodeship in 2004 and was comparable with the production per employee in western or central Poland from 2009 to 2010.

- In 2004, labor productivity in the voivodeships of western Poland accounted for $72.2 \%$ of the value of this variable in the Mazowieckie Voivodeship, while in 2016 it was only 67\%. Similar indicators for the remaining groups of voivodeships are as follows: in central Poland, 68.1\% 
and $64.9 \%$, while in eastern Poland, $51.1 \%$ and $50.9 \%$. This means that in terms of labor productivity (similar to the GDP per capita analyzed in Chapter 3), the gap between the Mazowieckie Voivodeship and the rest of the country is widening.

- In contrast to GDP or to per capita GDP, which are variables both in the Polish economy as a whole and in groups of voivodeships, the workforce productivity increased the fastest before the global financial crisis, while the slowest growth performance during the crisis itself (of work forced productivity) was in the Mazowieckie Voivodeship and the voivodeships of eastern Poland. It grew the fastest during the global financial crisis (at an annual average rate of $6.6 \%$ in the Mazowieckie Voivodeship and $6.1 \%$ in eastern Poland, respectively), and growth was slower before and after the financial crisis. What's more, also in the voivodeships of central and western Poland, production growth rates for those employed after 2013 dropped (from 4.1 to $3.5 \%$ in central Poland and from 5.3 to $-0.5 \%$ in western Poland, respectively). This can be explained by the hypothesis of unemployed economic growth (cf. e.g. Kwiatkowski et al. 2004 or Kotlorz, Sojka 2017). During the global financial crisis, the Polish economy experienced a significant slowdown in economic growth - the GDP growth rate fell below the rate of labor productivity growth resulting from capital accumulation and technological progress. This resulted in a decrease in labor demand, a decrease in employment and an increase in unemployment. This effect was an increase (with positive GDP growth rates) in labor productivity. However, after 2013, the demand for labor in Poland began to increase, which led to a decrease in the rate of labor productivity growth.

Map 7.2 presents the average levels of wages in voivodeships in the years 2004-2017, Figure 7.6 - the trajectories of this variable in groups of voivodeships. The following conclusions can be drawn from Map 7.2 and Figure 7.6 (see also Tokarski 2005b, 2012; Roszkowska, Rogut 2007; Adamczyk et al. 2009; Misiak, Tokarski 2012 or Adamczyk 2015):

- As in the case of GDP per capita or labor productivity, the highest wages were also recorded in the Mazowieckie Voivodeship (on average in 2004-2017 PLN 4,654.48). In the Śląskie (3,813.20 zlotys), Dolnośląskie (3,725.98 zlotys) and Pomorskie (3,707.35 zlotys) voivodeships, wages were higher than 3,500 PLN. The lowest level of wages (below PLN 3,200 ) was recorded in the Podkarpackie (PLN 3,125.46), WarmińskoMazurskie (PLN 3,126.35) as well as Lubuskie (3,181.68 PLN) and Kujawsko-Pomorskie (PLN 3,181.91) voivodeships.

- Comparing the spatial diversity of wages with the diversity of labor productivity (Map 7.1) and unemployment rates (Map 7.3), it turns out that in voivodeships with a higher level of labor productivity and lower unemployment, wages were higher The correlation coefficient between 
[3125.455: 3181.681] (3) [3181.909: 3274.135] (3)

[3301.606: 3374.364$]$ (4)

[3403.712: 3707.347] (3)

[3725.978: 4654.481] (3)

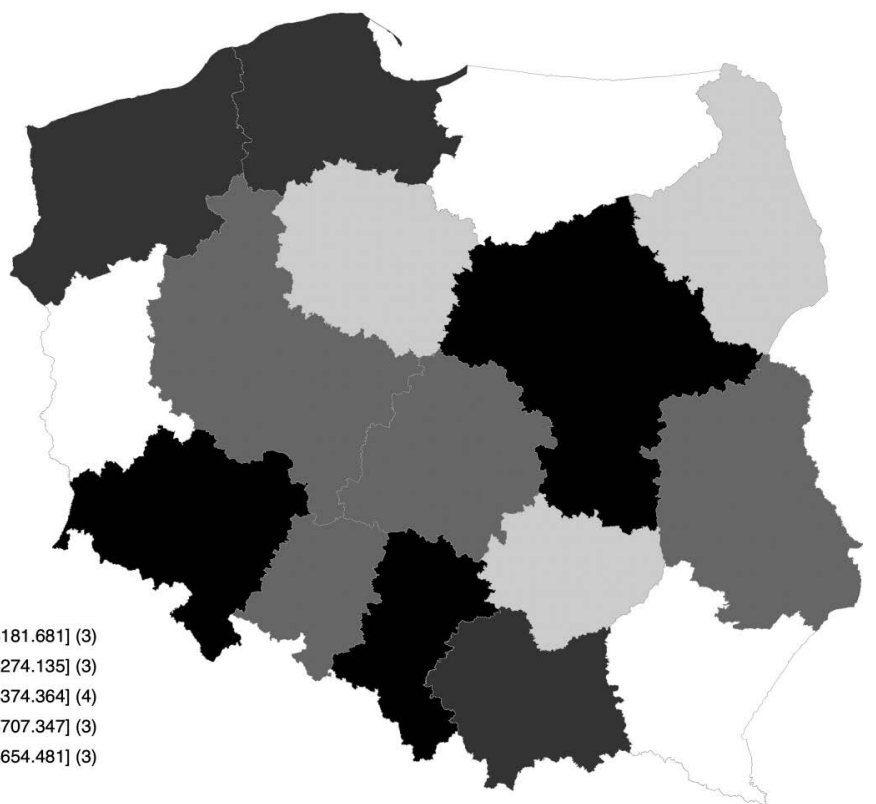

Map 7.2 Wages in Polish voivodeships in 2004-2017 (PLN, according to 2015 prices). Source: Our own estimates based on: https://bdl.stat.gov.pl/BDL/start (access: 2019-12-30).

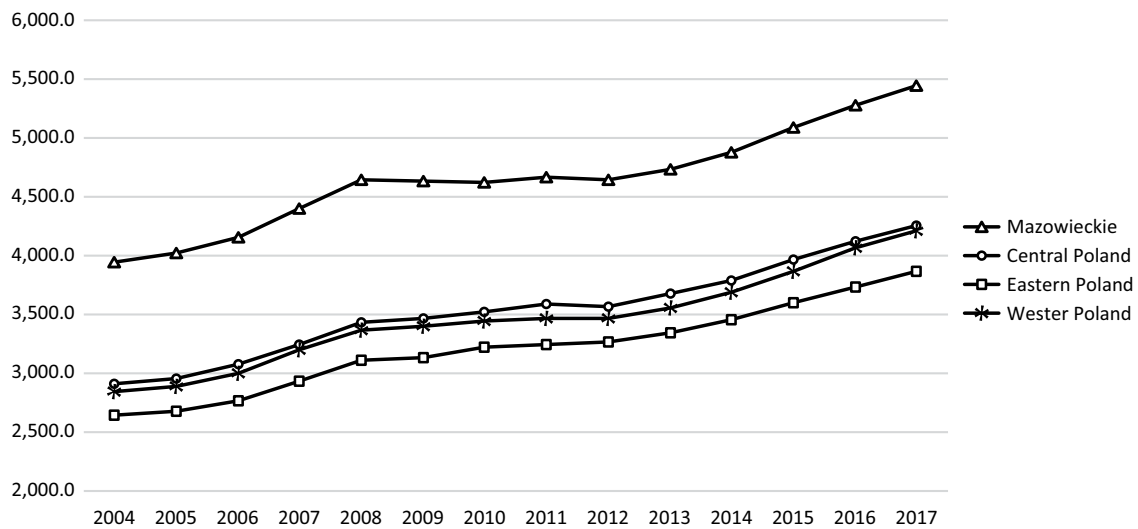

Figure 7.6 Wages in Polish voivodeships groups in 2004-2017 (PLN, according to 2015 prices).

Source: Our own estimates based on: https://bdl.stat.gov.pl/BDL/start (access: 2019-12-30). 
voivodeship wages and labor productivity (in 2004-2016) was 0.886 , and between wages and unemployment rates, 0.716 .

- In 2004-2017, overall wages in all Polish voivodeships were characterized by an upward trend. The highest (exceeding 50\%) wage increases were recorded in the Dolnośląskie (53.1\%), Małopolskie (52.1\%) and Łódzkie (51.2\%) voivodeships, whereas the lowest growth rate of this macroeconomic variable was recorded in the Świętokrzyskie (43.2\%), Śląskie (29.6\%) and Mazowieckie (38.3\%) voivodeships.

- Comparing wages in the Mazowieckie Voivodeship with the value of this feature in the other groups of voivodeships, it turns out that the wages in this voivodeship in 2004 (amounting to PLN 3,939.26) were slightly lower than the wages in the central (PLN 4,252.79) and western (PLN 4,205.69) voivodeships and higher than wages in eastern Poland (PLN 3,862.94) in 2017. ${ }^{7}$

- Before the global financial crisis (2004-2009) wages in the voivodeships of central and western Poland grew at an average annual rate of 3.6\%, in eastern Poland, 3.5\% and in the Mazowieckie Voivodeship, 3.3\%. An increase in unemployment during this crisis reduced the wage dynamics in Poland. The average annual growth rate of wages in 2010-2013 fell to $1.6 \%$ in eastern Poland, $1.5 \%$ in central Poland, $1.3 \%$ in western Poland and only $0.5 \%$ in the Mazowieckie Voivodeship. The economic recovery after 2013 combined with falling unemployment translated into a significant acceleration of the growth rate of the macroeconomic variable analyzed here in Poland. Wages in western Poland increased in 2014-2017 at a rate of 4.3\%, in central and eastern Poland at a rate of $3.7 \%$ and in the Mazowieckie Voivodeship at a rate of $3.6 \%$.

The spatial differentiation of unemployment rates in Poland in 2004-2017 is shown on Map 7.3. In contrast, Figure 7.7 shows the trajectories of this macroeconomic variable in groups of voivodeships. The following conclusions can be drawn from Map 7.3 and Figure 7.7 (see also Tokarski 2005a, b, Kwiatkowski, Tokarski 2007, Tokarski 2008, Misiak, Tokarski 2012, Dykas et al. 2013, Majchrowska et al. 2013, Trojak, Tokarski 2013, Trojak 2015, Gomółka et al. 2017 or Pastuszka, Tokarski 2017):

- The highest unemployment rates in the research period were in the Warmińsko-Mazurskie (20.0\%), Zachodniopomorskie (17.2\%) and Kujawsko-Pomorskie (16.5\%) voivodeships. The first two of these voivodeships and partly also the Kujawsko-Pomorskie Voivodeship are voivodeships which formerly possessed many (communist) state-owned collective farms. Thus, the liquidation of these state-owned farms (Państwowe Gospodarstwo Rolne, PGR) at the beginning of the transformation of the economic system led to high structural unemployment (see: Rogut, Tokarski 2001, 2002), which to a large extent still persists. ${ }^{8}$ 
[8.971: 9.979] (3)

[10.193: 12.493] (3)

[12.693: 13.264] (4)

$[14.971: 15.229](3)$

$[16.457: 20.007](3)$

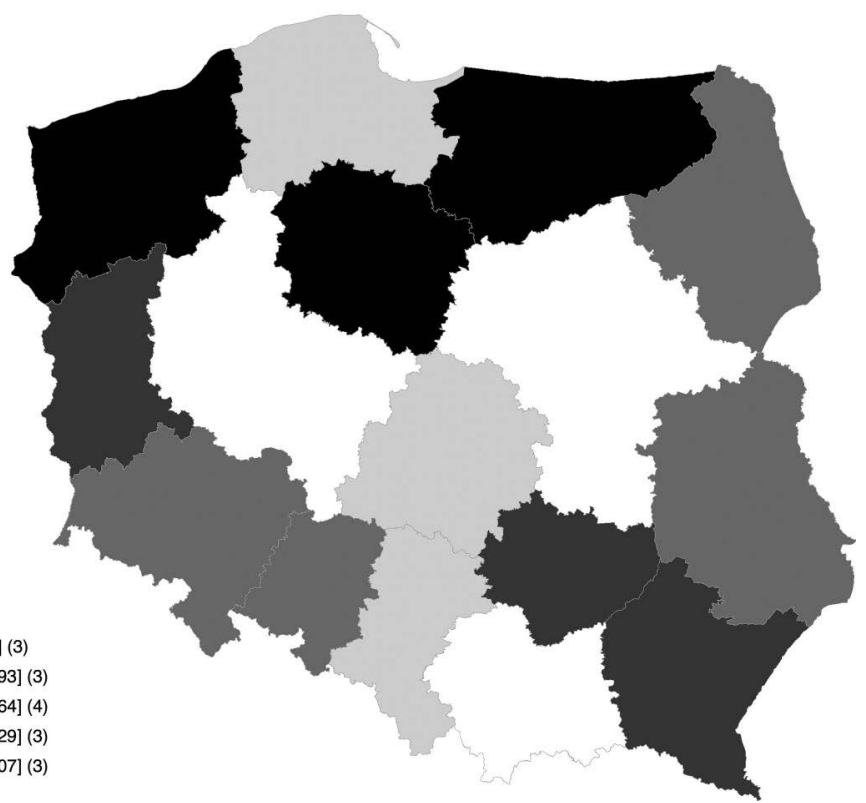

Map 7.3 The unemployment rates in voivodeships in 2004-2017 (in \%).

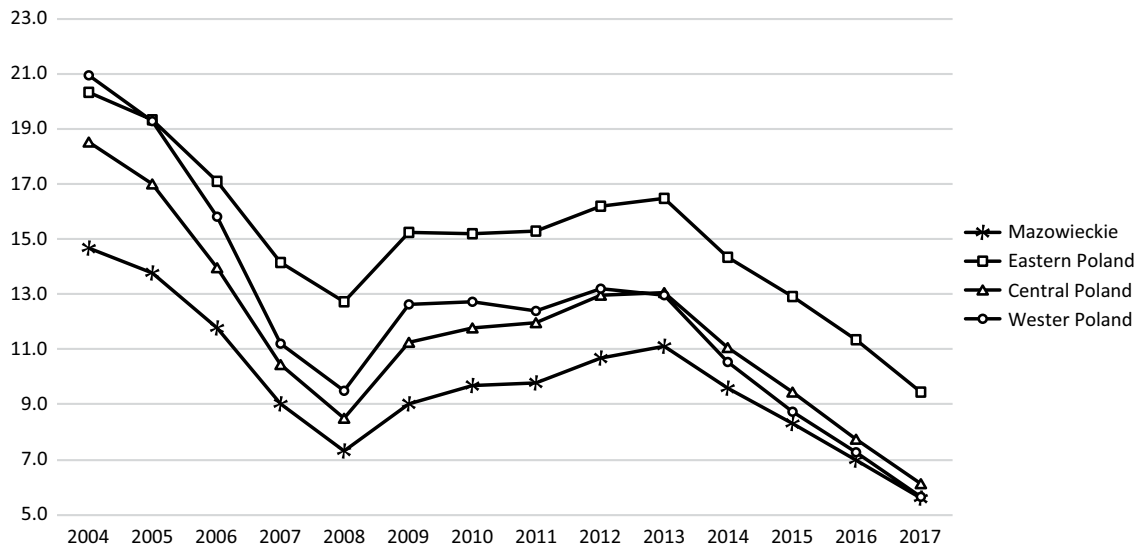

Figure 7.7 The unemployment rates in groups of voivodeships in 2004-2017 (in \%). Source: Our own estimates based on: https://bdl.stat.gov.pl/BDL/start (access: 2019-12-30). 
- The lowest unemployment rates were recorded in the following voivodeships: Wielkopolskie (9.0\%), Mazowieckie (9.8\%), Małopolskie $(10.0 \%)$ and Śląskie (10.2\%).

- In all voivodeships, the unemployment rates in 2017 were significantly lower than at the beginning of the research period. These rates fell most in those regions which liquidated state-run collective farms such as in the ${ }^{9}$ Lubelskie (from 25.6 to 5.6\%), Zachodniopomorskie (from 27.5 to $8.5 \%$ ) and Warmińsko-Mazurskie (from 29.2 to $11.7 \%$ ) voivodeships, and the least in three voivodeships of eastern Poland (Podlaskie from 16.1 to $8.5 \%$, Lubelskie from 17.8 to $8.8 \%$ and Podkarpackie from 19.1 to 9.6\%) as well as in the Mazowieckie (from 14.7 to 5.6\%) and Małopolskie (from 15.0 to $5.3 \%$ ) voivodeships.

- In 2004-2008, that is, immediately after Poland's accession to the European Union, the good situation of the economic cycle led to an increase in labor demand, an increase in employment and a decrease in unemployment. At that time, the unemployment rate in eastern Poland fell from 20.3 to $12.8 \%$, in western Poland from 21.0 to $9.5 \%$, in central Poland from 18.5 to $8.5 \%$ and in the Mazowieckie Voivodeship from 14.7 to $7.3 \%$.

- The global financial crisis has led to a significant slowdown in economic growth in Poland. This, in turn, translated into a decrease in demand for work and an increase in unemployment. The unemployment rate in eastern Poland increased until 2013, reaching 16.2\%, in western Poland it increased to $13.2 \%$, in central Poland it increased to $13.0 \%$, and in the Mazowieckie Voivodeship it rose to $10.7 \%$.

- The good economic cycle in 2014-2017 increased the demand for work, leading to an increase in employment and a decrease in unemployment. Unemployment rates in 2017 were at a level of $5.6 \%$ in the Mazowieckie Voivodeship and in western Poland, $6.1 \%$ in central Poland and $9.5 \%$ in eastern Poland.

Figure 7.8 presents the coefficient of the variation of labor productivity, wages and unemployment rates in Poland in the research period (defined as the relationship of standard deviations to the unweighted arithmetic mean of the analyzed variables). From this figure, the following conclusions can be drawn: First, the spatial diversity of wages was much smaller than the differences in labor productivity or unemployment rates. This resulted from the fact that wages in the public sector are loosely related to both the level of labor productivity and unemployment in a given voivodeship. Second, the spatial diversity of wages in 2004-2017 was characterized by a certain convergence tendency (the coefficient of variation of this variable fell from 0.117 to 0.102 ). Third, the spatial diversity of unemployment rates in Poland in times of prosperity grows, while in weak economic conditions it decreases. Fourth, the spatial diversity of labor productivity is relatively stable. 
0.350

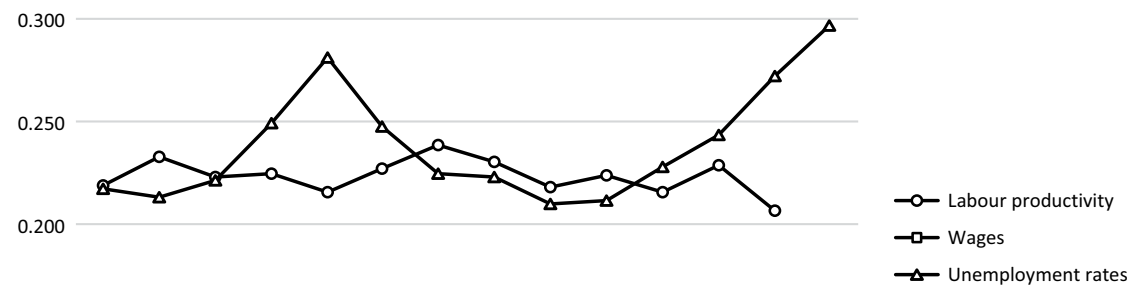

0.150

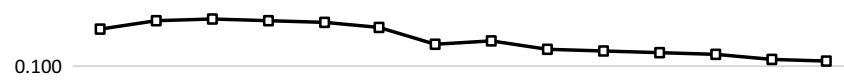

0.050

$200420052006200720082009201020112012 \quad 20132014201520162017$

Figure 7.8 Coefficients of the variability of labor productivity, wages and unemployment rates in Poland in 2004-2017.

Source: Our own estimates based on: https://bdl.stat.gov.pl/BDL/start (access: 2019-12-30).

\subsubsection{Differentiation in labor productivity, wages and unemployment rates in Ukraine}

Map 7.4 presents the spatial differentiation of labor productivity in the oblasts of Ukraine in 2004-2017. ${ }^{10}$ Trajectories of this variable in oblast groups are illustrated in Figure 7.5. Map 7.4 and Figure 7.9 show the following (see also Pustovoit 2016, Chugaievska et al. 2017, Chugaievska, Tokarski 2018 or Tokarski et al. 2019):

- As in the case of GDP per employee, the highest level of labor productivity was also recorded in Kyiv (364.4 thousand UAH). A high value of this trait, in Ukraine, was also characteristic of the Dnipropetrovsk (172.1 thousand UAH) and Poltava oblasts (164.9 thousand UAH) in central Ukraine, Donetsk (157.6 thousand UAH) in eastern Ukraine and Kyiv (147.0 thousand UAH) in the north of Ukraine.

In the case of the Autonomous Republic of Crimea and Sevastopol in 2004-2013.

- The lowest (less than 80 thousand UAH) labor productivity was recorded in the Kherson Oblast (77.7 thousand UAH) in the south of Ukraine and in the Ternopil (74.7 thousand UAH), Zakarpattia (69.2 thousand UAH) and Chernivtsi (62.9 thousand UAH) oblasts in western Ukraine. 


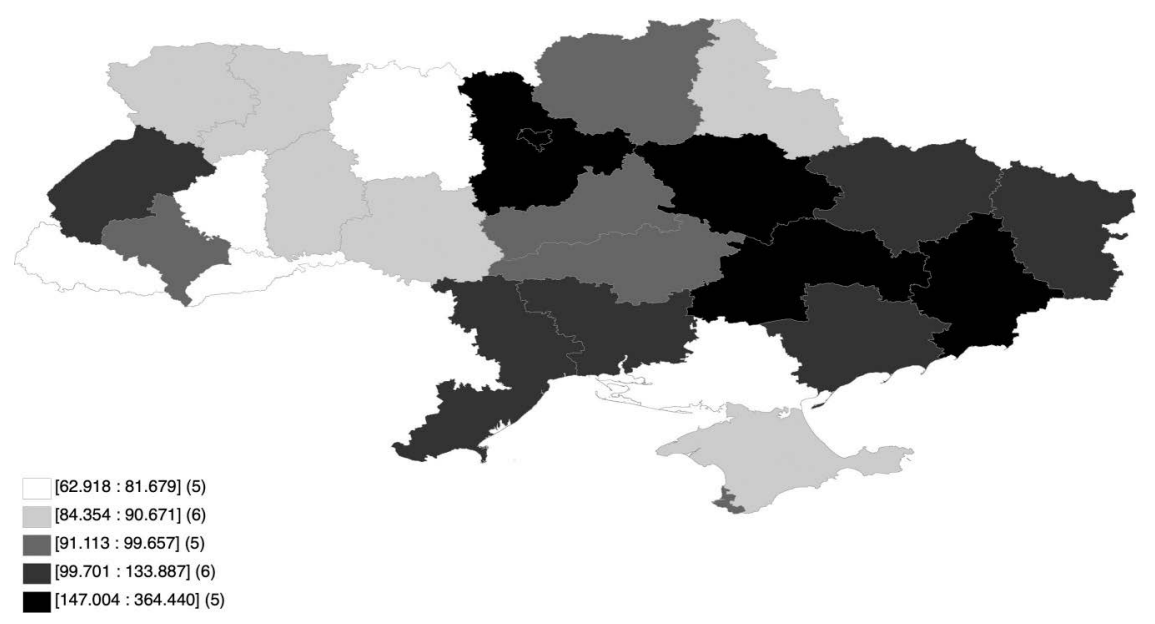

Map 7.4 Labor productivity in the oblasts in the years 2004-2017 (1,000 UAH, prices 2016).

Source: Our own estimates based on: http://www.ukrstat.gov.ua/ (access: 2019-12-30).

300.0

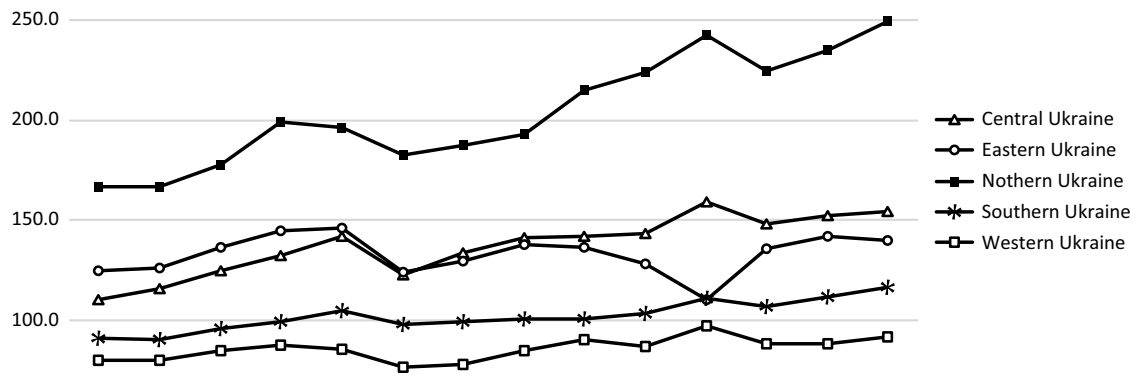

$50.0 \begin{array}{llllllllllllll}2004 & 2005 & 2006 & 2007 & 2008 & 2009 & 2010 & 2011 & 2012 & 2013 & 2014 & 2015 & 2016 & 2017\end{array}$

Figure 7.9 Labor productivity in oblast groups in 2004-2017 (1,000 UAH, according to 2016 prices).

In the case of the Autonomous Republic of Crimea and Sevastopol in2004-2013.

Source: Our own estimates based on: http://www.ukrstat.gov.ua/ (access: 2019-12-30).

- This is because Left-bank Ukraine and the Odesa and Mykolayiv oblasts are characterized by a higher capital-labor ratio of labor and (often) stronger gravitational effects than Right-bank Ukraine (Chugaievska et al. 2017), so the level of labor productivity in these areas was generally higher than in the west of Ukraine. 
- In 21 out of 25 Ukrainian oblasts (excluding the Autonomous Republic of Crimea and Sevastopol) labor productivity in 2017 was higher than in 2004 (although in the Ivano-Frankivsk Oblast production per employee increased only by $1.7 \%$, i.e., $0.1 \%$ annual average).

- The highest (exceeding 30\%) increases in this macroeconomic variable were recorded in the Kyiv Oblast $(73.9 \%, 4.3 \%$ on average per year) and Kyiv City $(44.1 \%, 2.8 \%)$ in the north of Ukraine and in the Vinnytsya $(37.3 \%, 3.4 \%)$ and Cherkasy $(40.9 \%, 2.7 \%)$ oblasts in the center of the country. The highest increases in labor productivity were recorded in the Kyiv Oblast $(73.9 \%, 4.3 \%$ on average per year) and the City of Kyiv $(44.1 \%, 2.8 \%)$ in northern Ukraine and the Vinnytsya $(54.4 \%, 3.4 \%)$ and Cherkasy $(40.9 \%, 2.7 \%)$ oblasts in central Ukraine. Labor productivity in the Autonomous Republic of Crimea increased in 2004-2013 by $24.4 \%$ (2.5\% on average per year), while in Sevastopol by $32.9 \%(3.2 \%)$.

- Similar trends in labor productivity can be seen in all the oblast groups (except in eastern Ukraine). In the years 2004-2008 the value of this variable increased, and in 2009 it decreased significantly. This decrease was the result of both the global financial crisis and the gas conflict with Russia. In 2010-2014 (and thus until the Euro-Maidan) the GDP per working person began to grow again. In 2015, the level of this variable decreased. The increase in labor productivity in 2016-2017 was due to the fact that the Ukrainian economy recorded the first symptoms of economic recovery after the crisis caused by the political perturbations after the Euro-Maidan (in 2016 the Ukrainian GDP increased by $2.4 \%$, and in 2017 by $2.5 \%$ ).

- By far the highest level of GDP per working person was recorded in the regions of northern Ukraine, where the value of this variable increased from 166.6 thousand UAH in 2004 to 249.2 thousand UAH in 2017. In eastern Ukraine, labor productivity increased from 124.4 thousand UAH to 139.7 thousand UAH, in central Ukraine from 110.0 thousand UAH to 154.4 thousand UAH, in the south from 91.3 thousand UAH to 116.6 thousand UAH, and in the west from 80.0 thousand UAH to 91.5 thousand UAH. Thus, the value of this variable grew the fastest in the best-developed northern Ukraine (3.1\% on average per year), and the slowest in the industrial and mining oblasts of eastern Ukraine $(0.9 \%)$.

Map 7.5 presents the spatial diversity of wages in Ukraine, while Figure 7.10 shows the trajectories of this variable in oblast groups in 2004-2015. The following conclusions can be drawn from the map and graph (see also, for example, Chugaievska et al. 2017, Bolińska, Gomółka 2017 or Tokarski et al. 2019):

- As in the case of labor productivity, the highest wages were recorded in the capital of Kyiv (on average in 2004-2017 8386.05 UAH). The Donetsk (5,990.33 UAH), Dnipropetrovsk (5,481.32 UAH), Kyiv (5,330.82 UAH) 
and Zaporizhzhya (5,239.78 UAH) oblasts also had a high value of the macroeconomic variable analyzed here.

- The lowest wages occurred in the Chernivtsi (4,012.08 UAH), Volyn (4,005.88 UAH) Ternopil (3,763.51 UAH) and Kherson (4,009.66 UAH) oblasts in the west of Ukraine and in the Chernihiv $(4,000.78) \mathrm{UAH})$ Oblast in the north of the country.

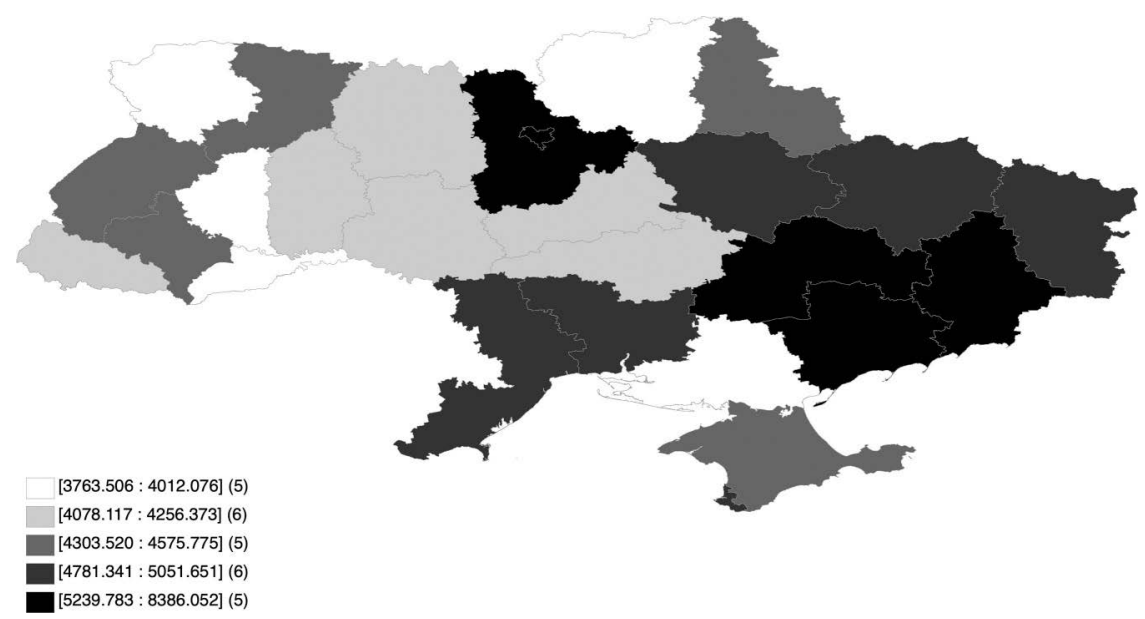

Map 7.5 Wages in Ukrainian oblasts in 2004-2017 (UAH, according to 2016 prices). Source: Our own estimates based on: http://www.ukrstat.gov.ua/ (access: 2019-12-30).

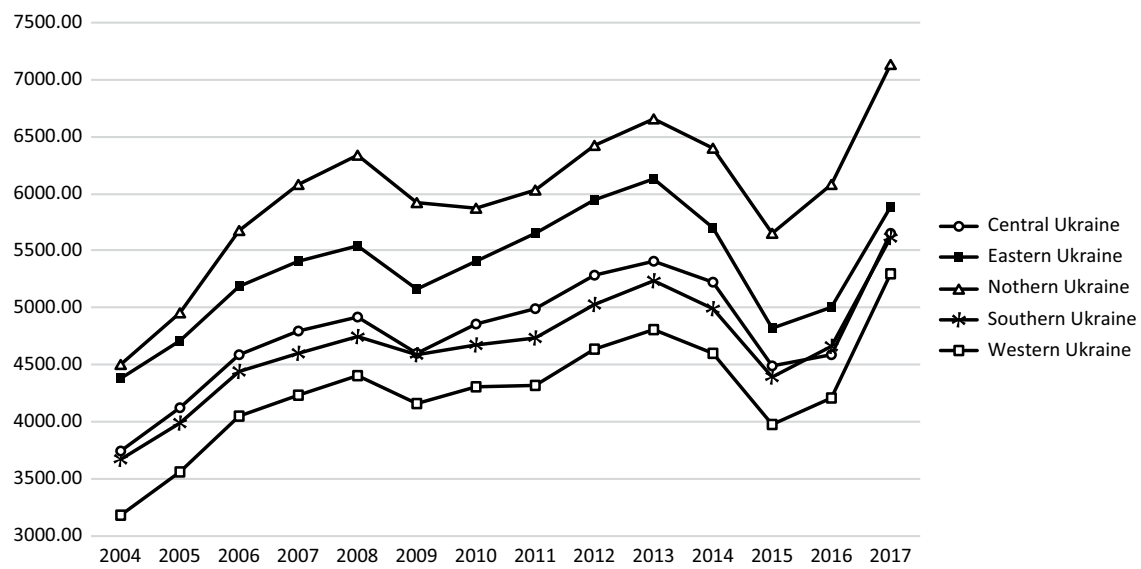

Figure 7.10 Wages in groups of oblasts in 2004-2017 (UAH, according to 2016 prices).

Source: Our own estimates based on: http://www.ukrstat.gov.ua/ (access: 2019-12-30). 
- In all oblasts, wages in 2017 were higher than at the beginning of the research period. The fastest value of this variable grew in the Ternopil (by $85.2 \%, 4.9 \%$ on average per year), Volyn $(83.7 \%, 4.8 \%$, respectively) and Khmelnytskiy $(83.4 \%, 4.8 \%)$ oblasts in western Ukraine and in the Vinnytsya $(82.1 \%, 4.7 \%)$ Oblast in central Ukraine. The lowest wage increases were recorded in the Dnipropetrovsk (34.6\%, 2.3\%) Oblast in central Ukraine and the Zaporizhzhya (32.4\%, 2.2\%) and Luhansk $(27.3 \%, 1.9 \%)$ oblasts in the eastern Ukraine. In the Autonomous Republic of Crimea, wages in 2004-2013 increased by $41.1 \%$ (3.9\% on average per year), while in Sevastopol by $41.0 \%$ (3.9\%).

In the case of the Autonomous Republic of Crimea and Sevastopol in 2004-2013.

- The spatial diversity of wages in Ukraine largely coincided with the diversity of labor productivity. The correlation coefficient between these variables was 0.946 . On the other hand, the correlation coefficient between wages and unemployment rates considered below is 0.586 .

- Wage trajectories in oblast groups were similar in shape to both the trajectory of GDP and labor productivity. This is due to the fact that labor productivity has largely affected the level of wages in Ukraine.

- In Ukraine northern, wages increased from 4,499.27 UAH in 2004 to $7,130.00 \mathrm{UAH}$ in 2017, in the east from 4,373.79 UAH to 5,881.58 UAH, in central Ukraine from 3,741.65 UAH to 5,654.84 UAH, in the south from $3,669.01 \mathrm{UAH}$ to $5,614.69 \mathrm{UAH}$, while in the poorest region, that is western Ukraine, from 3,176.35 UAH to 5,291.34 UAH. Thus, the highest average annual wage dynamics were observed in the group of western Ukraine oblasts (4.0\%), while the lowest in eastern Ukraine (2.3\%).

Map 7.6 illustrates the spatial differentiation of unemployment rates in Ukrainian oblasts (on average in 2004-2017), while Figure 7.11 shows trajectories of this macroeconomic variable in groups of oblasts. The following conclusions can be drawn from the aforementioned map and figure (see also, e.g., Lysiuk, Kaflevska 2012, Paniuk 2013, Homiak 2015, Yarova 2015, Chugaievska et al. 2017, Chugaievska, Tokarski 2018 or Tokarski et al. 2019):

- The lowest average unemployment rates in the period under consideration were recorded in the two cities with a special status (Sevastopol 5.0\% and Kyiv 5.3\%) and the Autonomous Republic of Crimea (5.7\%) and in the Odesa Oblast (5.9\%) in southern Ukraine. The highest level of this variable was recorded in the Zhytomyr Oblast (10.1\%) in the north of Ukraine, as well as in the Ternopil (10.3\%) and Rivne (10.4\%) oblasts in western Ukraine. High unemployment rates also occurred in the Chernihiv Oblast (9.8\%) in the north and the Kirovohrad Oblast (9.7\%) in central Ukraine. 


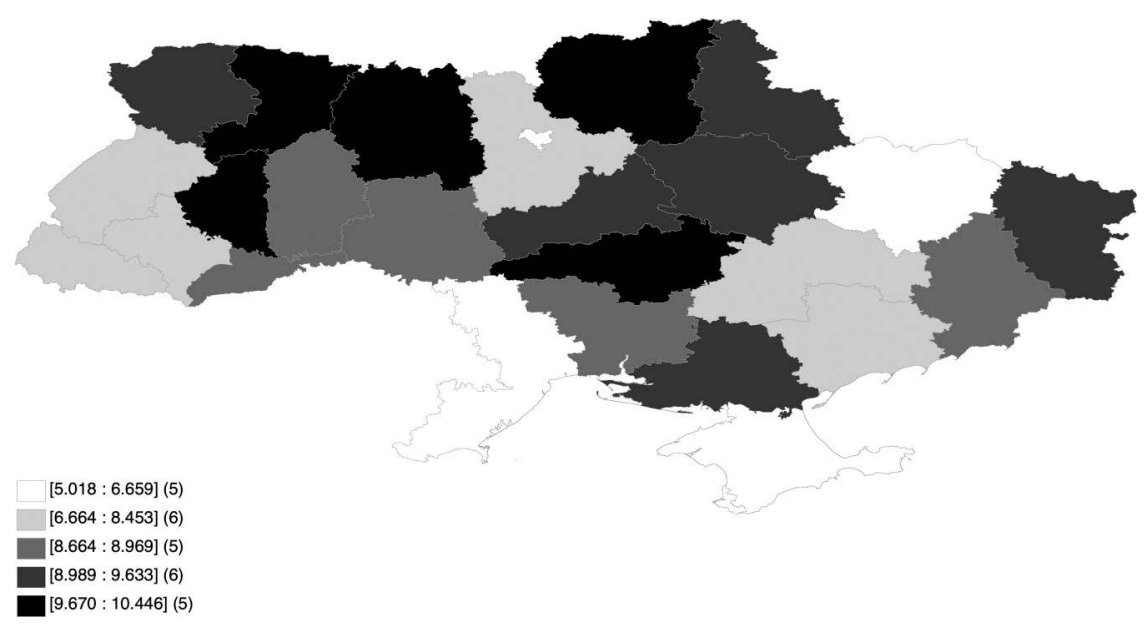

Map 7.6 The unemployment rates in oblasts in 2004-2017 (in \%).

Source: Our own estimates based on: http://www.ukrstat.gov.ua/ (access: 2019-12-30).

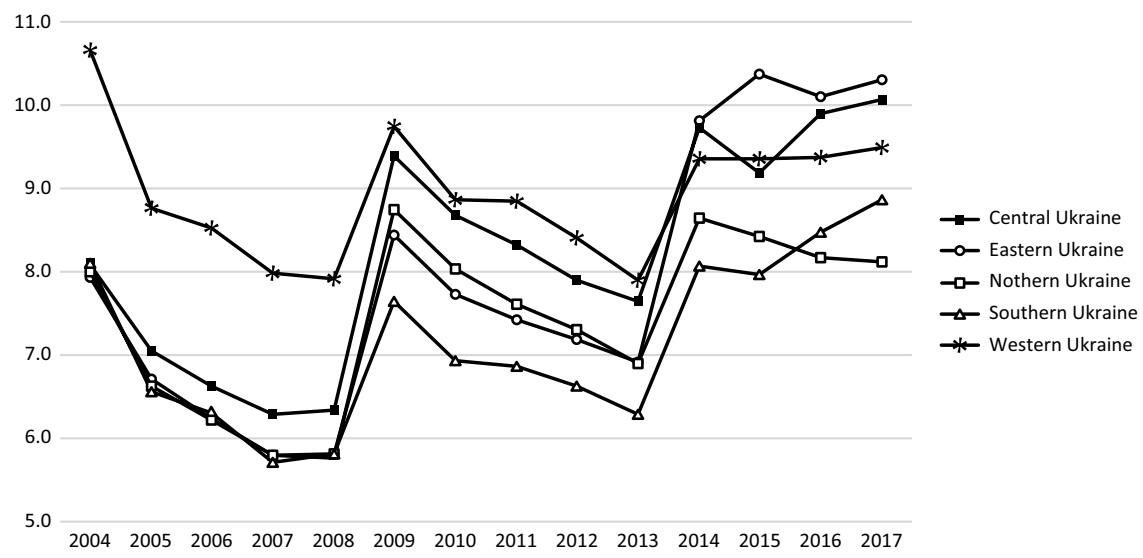

Figure 7.11 The unemployment rates in group of oblasts in 2004-2017 (\%). Source: Our own estimates based on: http://www.ukrstat.gov.ua/ (access: 2019-12-30).

In the case of the Autonomous Republic of Crimea and Sevastopol in 2004-2013.

- The spatial differentiation of unemployment rates in Ukraine partially coincided with the spatial differentiation of labor productivity and wages in the sense that the higher the labor productivity or wages, the lower the unemployment rates were. The correlation coefficient between these rates and labor productivity was -0.499 , and between unemployment rates and wages -0.586 . 
- In 12 Ukrainian oblasts, unemployment rates in 2017 were lower than in 2004, while in the remaining 13 they were higher. The group of oblasts in which unemployment rates fell included the following regions: Chernivtsi, Khmelnytskiy, Ivano-Frankivsk, Lviv, Rivne and Ternopil in western Ukraine; Kyiv, Sumy and Zhytomyr in the north of Ukraine; Kharkiv in the east of Ukraine; Mykolayiv in the south; and the Cherkasy Oblast in central Ukraine. The largest decreases in unemployment rates were recorded in the following regions: Chernivtsi by $3.8 \%$ points (from $12.2 \%$ in 2004 to $8.4 \%$ in 2017 ), Lviv by $2.5 \%$ points (from 10.0 to $7.5 \%$ ) and Khmelnytskiy by $2.4 \%$ points (from 11.1 to $8.7 \%$ ), while the highest increases were in the Poltava by $4.5 \%$ points (from 7.4 to $11.9 \%$ ), Donetsk by $7.1 \%$ points (from 7.4 to $14.5 \%$ ) and Luhansk oblasts by $7.4 \%$ points (from 9.2 to $16.5 \%$ ). In the Autonomous Republic of Crimea, the unemployment rate fell from 6.9 to $5.9 \%$ in $2004-2013$, while in Sevastopol it increased from 5.3 to $5.7 \%$.

- A period of relative prosperity in the Ukrainian economy (20042008), when the GDP grew quickly, translated into an increase in employment combined with a decrease in unemployment in all groups of oblasts. Unemployment rates fell the fastest in western Ukraine (by $2.7 \%$ points), in northern and southern Ukraine $(2.3 \%$ points) and in eastern Ukraine (2.1\% points), and the slowest in central Ukraine (1.7\% points). As a result, the difference between the group of oblasts with the highest value of this variable (western Ukraine) and the group with its lowest value (eastern Ukraine) fell from 2.7\% points in 2004 to $2.1 \%$ points in 2008 .

- The global financial crisis, combined with the Russian-Ukrainian gas conflict, translated into a one-year recession, which also resulted in a significant increase in unemployment rates in all oblast groups. At the time, these rates rose the fastest in the oblasts of central Ukraine (by $3.1 \%$ points), then in the northern (3.0\% points) and eastern ( $2.6 \%$ points) oblasts. The slowest increase was in the south and west of Ukraine (by $1.8 \%$ points).

- Economic growth in Ukraine in the years 2010-2013 again led to a decrease in the variable analyzed here, in all oblast groups. The highest decreases in unemployment rates were then recorded in western Ukraine (1.9\% points), while the lowest in southern Ukraine (1.4\% points).

- The economic, political and military crisis after the Euro-Maidan caused a surge in unemployment rates in all groups of Ukrainian oblasts. These rates increased from $7.9 \%$ in 2013 to $9.4 \%$ in 2014 in western Ukraine, from 7.6 to $9.7 \%$ in central Ukraine, from 6.9 to $9.8 \%$ in eastern Ukraine, from 6.9 to $8.6 \%$ in the north and from 6.3 to $8.6 \%$ in southern Ukraine.

- In 2015-2017, the unemployment rates in all groups of Ukrainian oblasts stabilized, except for the oblasts of northern and southern Ukraine. In the north they began to rise slightly, while in the south they fell insignificantly. 


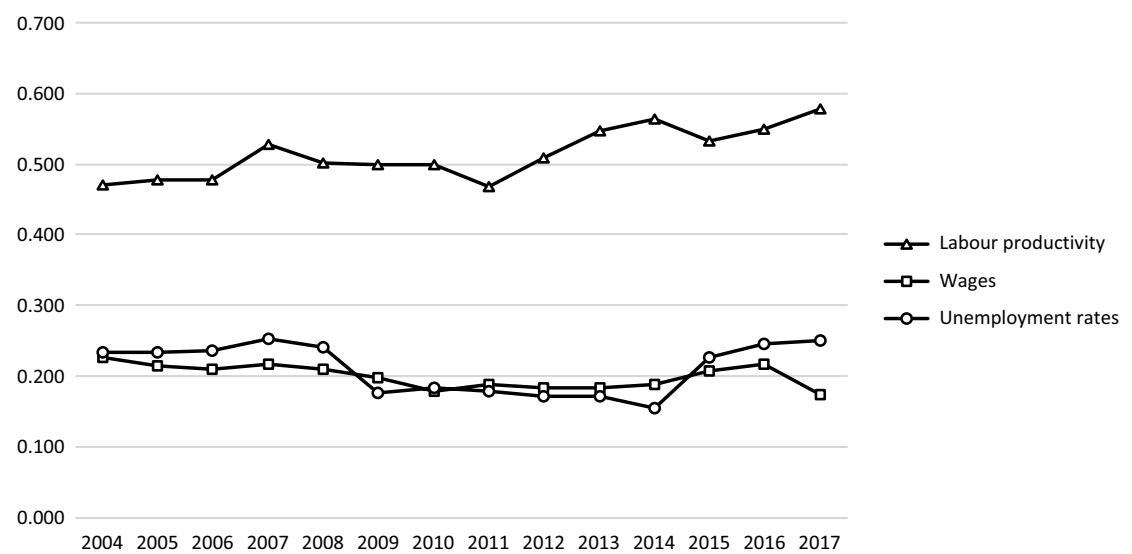

Figure 7.12 Coefficients of variability of labor productivity, wages and unemployment rates in Ukraine in 2004-2017.

Source: Our own estimates based on: http://www.ukrstat.gov.ua/ (access: 2019-12-30).

Figure 7.12 presents the coefficients of variation of the analyzed macroeconomic variables in Ukrainian oblasts in 2004-2017. The following conclusions can be drawn from this figure: First of all, labor productivity was much more spatially diverse than wages and unemployment rates. Second, the diversity of labor productivity in Ukraine was greater than the diversity of this macroeconomic variable in Poland. Third, the spatial diversification of labor productivity in Ukraine (as a trend) increased. Fourth, the differences in wages and unemployment rates were similar and quite stable.

\subsection{Determinants of the increase in unemployment rates and gross real wages - a theoretical approach and empirical verification}

In order to determine the main determinants of the increase in unemployment rates, one can rely on the definition of the unemployment rate of the equation $u_{i t}=\frac{U_{i t}}{U_{i t}+L_{i t}}$ (where $U_{i t}$ and $L_{i t}$ means the number of unemployed and working persons in the $i$-this voivodeship or oblast respectively in a given year $t$ ). Differentiating this equation (after time $\mathrm{t}$ ) and making simple transformations, we conclude that:

$$
u_{i t}^{\prime}=\left(1-u_{i t}\right) \cdot\left[\frac{N_{i t}^{\prime}}{N_{i t}}-\frac{L_{i t}^{\prime}}{L_{i t}}\right] \text {. }
$$

Equation (7.1) shows that the increase in the unemployment rate $u_{i t}^{\prime}$ depends on its $u_{i t}$ level and the difference between the labor supply growth rate $N_{i t}^{\prime} / N_{i t}$ and the employment growth rate $L_{i t}^{\prime} / L_{i t}$. 
Assuming that the employment growth rate $L_{i t}^{\prime} / L_{i t}$ is higher, the higher the product growth rate $g$ and by using the relationship (7.1), we arrive at an equation for the growth of the unemployment rate of the form of (see also Dykas et al. 2013):

$$
u_{i t}^{\prime}=\left(1-u_{i t}\right) \cdot\left[\frac{N_{i t}^{\prime}}{N_{i t}}-f(g)\right] \text {, }
$$

where $\frac{L^{\prime}}{L}=f(g)$ and $f^{\prime}(g)>0$. This equation (7.2) shows the following conclusions: First, an increase in the unemployment rate is a decreasing function of the product growth rate $g$ and second if the labor supply rate is higher (lower) from the employment growth rate, the increase in the unemployment rate is a decreasing (increasing) function of the unemployment rate.

While analyzing the factors determining wages, the following reasoning can be used, resulting from the Solow 1979 efficiency wage model and the neoclassical Solow 1956 economic grow th model and its generalizations (Tokarski 2005a, b or Dykas, Misiak 2014). This model shows that the higher the regional level of wages is, the higher the regional labor productivity is, and the lower the regional unemployment rate is as well. So we have the following equation:

$$
w_{i t}=\alpha_{0}-\alpha_{1} \cdot u_{i t}+\alpha_{2} \cdot y_{i t},
$$

where $w_{i t}$ means wages in the region $i$ and in a year $t, y_{i t}$ is labor productivity, and $u_{i t}$ is the unemployment rate.

Statistical analyzes of the impact of the real GDP growth rate (labor productivity) on the unemployment rate (gross real wages) in 2004-2017 were conducted based on panel data for Poland and Ukraine:

- Poland - 16 voivodeships, corresponding to the NUTS2 classification

- Ukraine - 27 oblasts, while for the Autonomous Republic of Crimea and Sevastopol, data refer to the period of 2004-2013.

The simple theoretical models presented in point 7.3 show that the impact of the GDP growth rate on the increase in unemployment rates as well as the impact of the unemployment rate and the level of labor productivity on the level of gross real wages can be established using the following equations:

$$
\Delta u_{i t}=\beta_{0}-\beta_{1} u_{i t-1}+\beta_{2} d_{\Delta u} u_{i t-1}+\beta_{3} \Delta \ln Y_{i t},
$$

and:

$$
\ln w_{i t}=\alpha_{0}-\alpha_{1} u_{i t}+\alpha_{2} \ln y_{i t}
$$


where $u_{i t}$ is the unemployment rate in the voivodeship (oblast) and in a given year $t, \Delta u_{i t}$ is the increase in the unemployment rate, and $d_{\Delta u}$ is the dummy variable taking the value 1 when the unemployment rate in the voivodeship (oblast) $i$ and in a year $t$ increased, zero in other cases; $\Delta \ln Y_{i t}$ is the real GDP growth rate in the voivodeship (oblast) $i$ in a year $t ; w_{i t}$ is the average gross real wage in a voivodeship (oblast) and $i$ in a year $t ; y_{i t}$ is the level of labor productivity in the voivodeship (oblast) $i$ in a year $t ; \beta_{0}$ is a constant that has no direct economic interpretation; $\beta_{1}>0$ measures the strength of the impact of the unemployment rate on the increase in the unemployment rate when the rate is not rising; $\beta_{2}>0$ measures the impact of the unemployment rate on the increase of this rate when the unemployment rate increases; $\beta_{3}$ describes the impact of the real GDP growth rate on the increase in the unemployment rate; $\alpha_{0}$ is constant without direct economic interpretation; $\alpha_{1}$ is a relative decrease in wages in the voivodeship (oblast) $i$ and in a year $t$ resulting from an increase in the unemployment rate by $1 \%$ point; $\alpha_{2}$ is wage flexibility in terms of labor productivity.

The above equations were estimated in two variants:

i In Variant I, Eqs. (7.4) and (7.5) were estimated using a two-step estimator based on the First Differences Generalized Method of Moments (FDGMM) by Arellano and Bond 1991.

ii Eqs. (7.4) and (7.5) were estimated in variant II using the System Generalized Method of Moments Estimator (SGMM) (Blundell and Bond 1998).

The results of this estimation of the parameters of these Eqs. (7.4) and (7.5) for variants I and II are summarized in Tables 7.1 and7.2.

From the estimation results summarized in Table 7.1 the following conclusions can be drawn:

- The estimated parameters of the equation for the increase in unemployment rates using both FDGMM and SGMM, when statistically significant, are also consistent with theoretical postulates as to the direction of the impact of explanatory variables on the increase in unemployment rates for both Poland and Ukraine.

- However, the values of estimated parameters for Poland and Ukraine differ significantly. Analyzing the results of estimation using FDGMM estimators, one can notice a large asymmetry of the impact of unemployment rates from the previous period, on the increase in unemployment rates depending on whether the previous unemployment rates increased or decreased. They had a more significant impact from the previous period, when they had a downward trend rather than an upward trend. This observation applies to both estimated parameters for Poland and Ukraine, with the difference that for Ukraine, the estimated parameter of the impact of the unemployment rate from the previous year, when the unemployment rate was falling, was not statistically significant. 


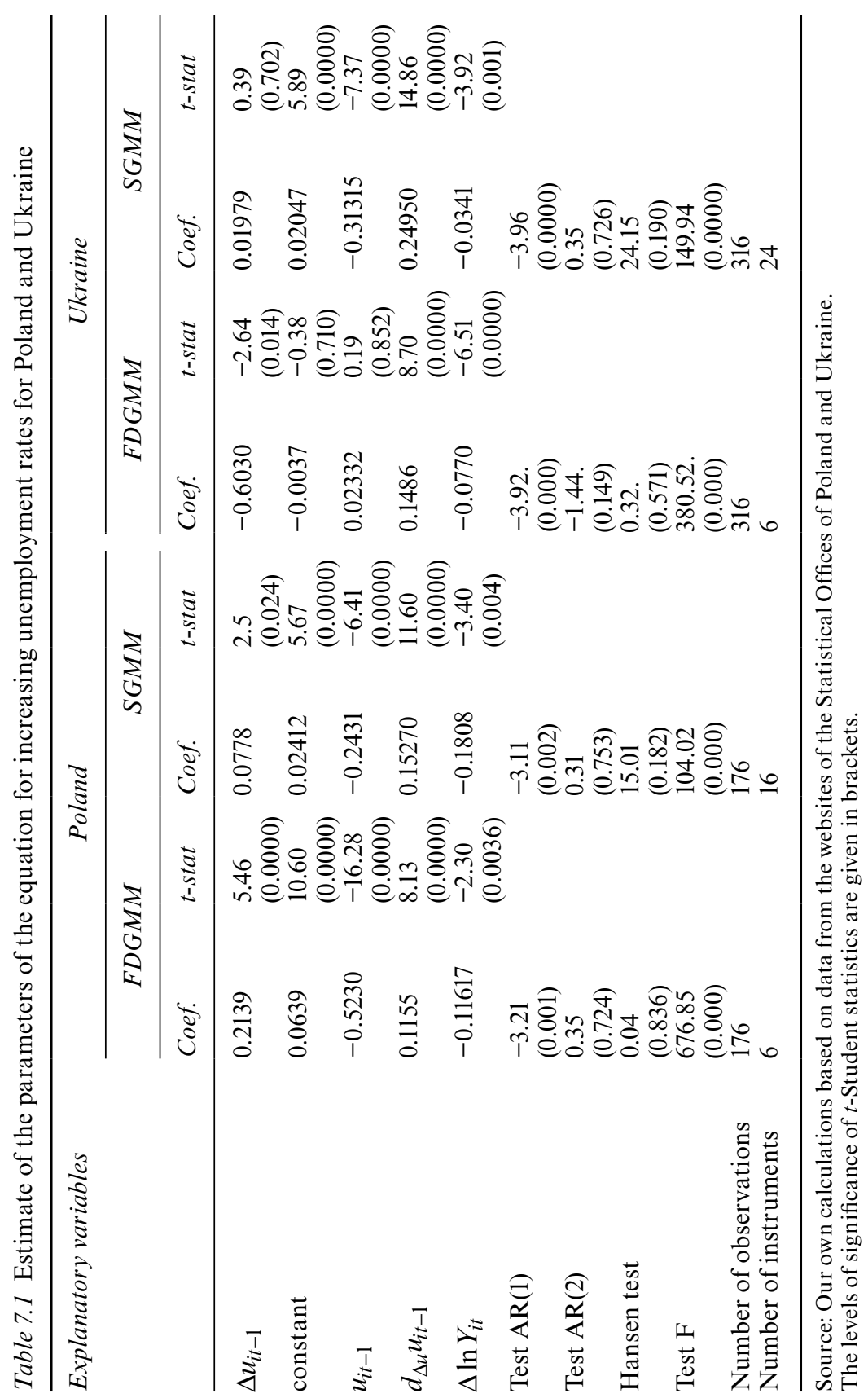




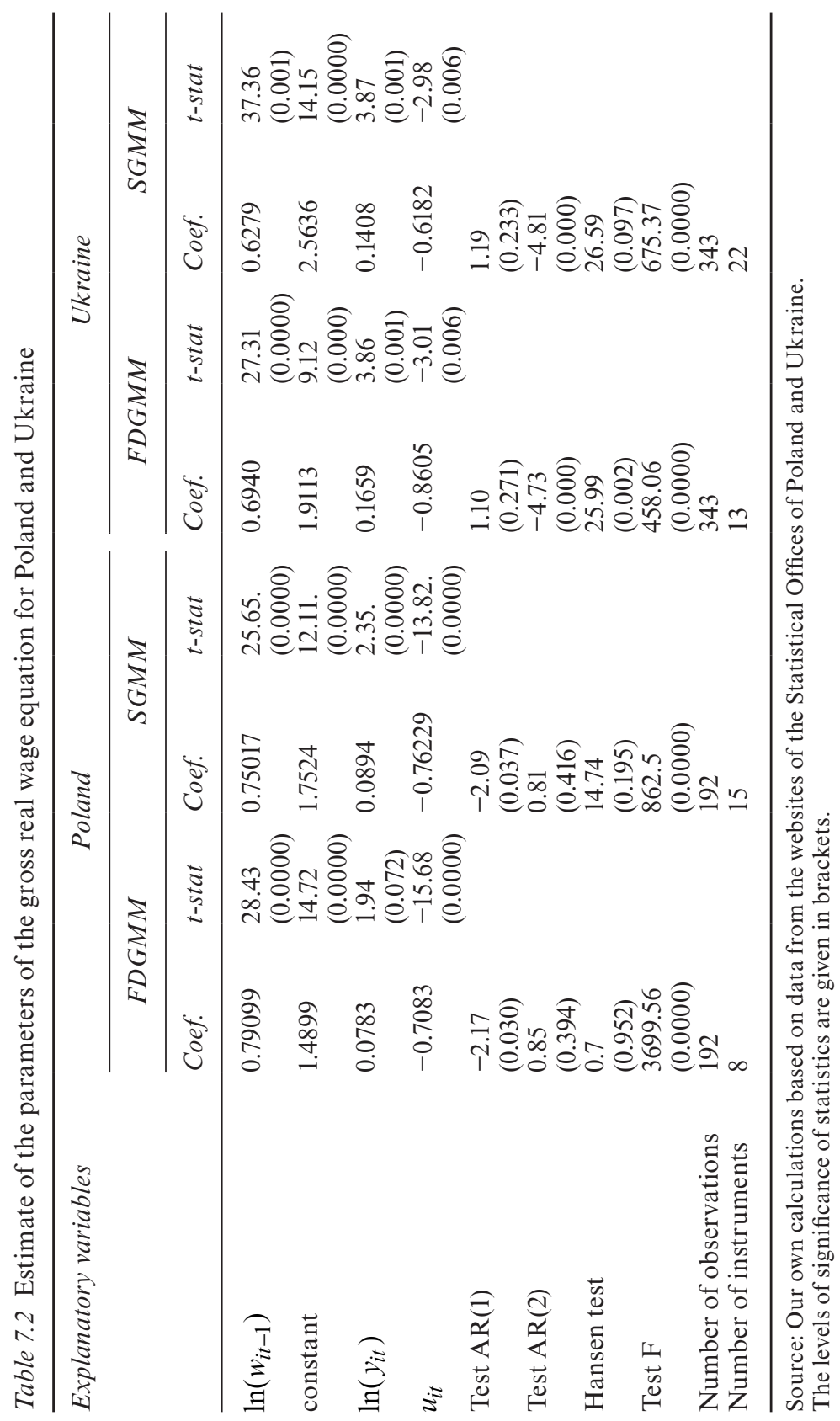


- Under decreasing unemployment rates, each subsequent percentage point of decrease in the unemployment rates in the previous year (ceteris paribus) reduced the increase in the unemployment rates in Poland by $0.243 \%$ points in an estimations using the SGMM and by 0.523 in estimates using the FDGMM, and in Ukraine by $0.313 \%$ points correspondingly, and in the estimations using the FDGMM this parameter was not statistically significant. However, in conditions of rising unemployment, each subsequent percentage point of increase in the unemployment rate in the previous year increased the growth of this variable in Poland by $0.153(0.116)$ of a percentage point in an estimation using the SGMM estimator (FDGMM), and in the Ukrainian economy respectively by $0.25(0.15)$ of a percentage point.

- An increase in the real GDP growth rate of $1 \%$ point resulted in a decrease in the unemployment rates of 0.181 of a percentage point in Poland and by 0.034 of a percentage point in Ukraine in estimations using the SGMM estimator and by 0.12 of a percentage point in Poland and by 0.08 of a percentage point in Ukraine in estimates from using the FDGMM estimator.

- Valuations employing the SGMM estimator several times (about 5.3 times) were more significantly influenced by an increase in the unemployment rate in Poland than in Ukraine.

- Analyzing the estimated parameters using the SGMM estimator, one can observe a smaller asymmetry of the impact of delayed unemployment rates, both in Poland and Ukraine. The difference in estimated parameters of the impact of economic growth rates was also smaller. For Poland, this parameter was about 56\% higher, and in Ukraine about $56 \%$ lower compared to the parameters estimated using the FDGMM.

- The instruments in both estimation variants were properly selected, as indicated by the Hansen test values. The obtained Hansen test statistics, as well as the significance levels obtained in variants I and II for both Poland and Ukraine, do not provide grounds for rejecting the zero hypothesis that all instruments in the model are exogenous.

- Satisfactory Arellano-Bond test values for AR (1) and AR (2) were also obtained, which indicate that a negative, statistically significant first order autocorrelation and a statistically insignificant second order autocorrelation were obtained in all estimation variants for both Poland and Ukraine. This demonstrates the compliance and effectiveness of the estimators used.

- Analyzing the results of the estimation of gross real wage equations using both FDGMM and SGMM estimators for Poland and Ukraine (summarized in Table 7.2), the following conclusions can be drawn:

- The estimated values of the parameters of the real wage equation using the FDGMM estimator for Poland and Ukraine were significantly different. The estimated values of the labor productivity impact parameter for Ukraine were almost two times higher than for Poland, suggesting 
that the increase in labor productivity in Ukraine determined the increase in wages more significantly than in Poland. This parameter in assessments using the SGMM estimator for the Ukrainian economy was about 58\% higher than for Poland.

- Estimates using the SGMM estimator show that when labor productivity increased by $1 \%$, real wages increased by $0.09 \%$ in Poland and by $0.14 \%$ in Ukraine.

- The estimated parameters of the impact of the unemployment rate on gross real wages, using the SGMM estimator, indicate that the unemployment rate in Poland exerted a more robust impact by approximately $23 \%$ on wages than in the Ukrainian economy.

- The parameters obtained using the SGMM for Poland and Ukraine are consistent with the theoretical assumptions made.

- According to an analysis of the Arellano-Bond test values for AR (1) and AR (2) for Poland, a statistically significant first-order autocorrelation and a statistically insignificant second-order autocorrelation were observed. The Hansen test values confirm that the instruments were correctly selected.

- In the estimation of the equation parameters of gross real wages for Ukraine, it can be stated that based on the Arellano-Bond tests for AR (1) and AR (2) a negative statistically significant second-order autocorrelation was observed. These Arellano-Bond test values for AR (2) significantly undermine the received estimates of the parameters of the gross real wage equation in Ukraine, and indicate that the obtained values could be significantly influenced by autocorrelation.

\subsection{Summary}

The considerations in this chapter can be summarized as follows:

i Among the voivodeships, the highest levels of labor productivity were recorded in (the Mazowieckie, Dolnośląskie and Wielkopolskie voivodeships. The smallest value of the discussed variable was recorded in three voivodeships of eastern Poland: Podlaskie, Świętokrzyskie and Podkarpackie).

ii In the Ukrainian economy, the highest level of labor productivity was recorded in (the capital of the country - Kyiv. The Dnipropetrovsk, Poltava and Donetsk oblasts also belonged to a group of high labor productivity oblasts. The lowest value of GDP per working person was in the Kherson, Ternopil and Zakarpattia oblasts).

iii The highest wages, in 2004-2017, occurred in the following voivodeships: (Mazowieckie, Śląskie and Dolnośląskie. On the other hand, the lowest wages in the Polish economy were recorded in the Podkarpackie, Warmińsko-Mazurskie and Lubuskie voivodeships).

iv In oblasts as a group, the highest wages occurred in the (capital City of Kyiv and in the oblast surrounding it - the Kyiv Oblast. High wages also 
occurred in the Dnipropetrovsk Oblast, whose capital, Dnipro, is the center of financial services in Ukraine. On the other hand, the lowest wages in the Ukrainian economy occurred in western Ukraine: in the Chernivtsi, Volyn and Ternopil oblasts).

v In the Polish economy, in the years 2004-2017, the highest unemployment rates were recorded in the following voivodeships: WarmińskoMazurskie, Zachodniopomorskie and Kujawsko-Pomorskie. The Wielkopolskie, Mazowieckie and Małopolskie voivodeships were characterized by the lowest unemployment rates in the research period.

vi The lowest average annual unemployment rates were recorded in those cities with a special status (Sevastopol and Kyiv) and in the Autonomous Republic of Crimea. The highest values of this variable, in 2004-2017, occurred in the Zhytomyr, Ternopil and Rivne oblasts.

vii In the conditions of decreasing unemployment rates, each subsequent percentage point of a decrease in unemployment from the previous year translated into a decrease of this variable in the current period, for the Polish economy, depending on the estimation method, by approx. $0.24-0.52$ of a percentage point, and for the Ukrainian economy by approx. 0.31 of a percentage point (for the SGMM estimates). However, in conditions of rising unemployment, each subsequent percentage point of increase in the unemployment rate from the previous year translated into an increase of approx. $0.15-0.12$ of a percentage point (in the case of Poland) and by approx. $0.15-0.25$ of a percentage point (in Ukraine) of the current unemployment rate.

viii An increase in the real GDP growth rate by $1 \%$ point, using the SGMM estimator, translated in the case of the Polish economy to a decrease in the unemployment rate by approx. 0.181, and in the Ukrainian economy by approx. 0.034 of a percentage point. However, when using the FDGMM estimator, these decreases were as follows: 0.12 of a percentage point for Poland and 0.08 of a percentage point for Ukraine.

ix Labor productivity statistically and significantly determined the level of wages in both the Polish and Ukrainian economy. Assessments using the SGMM estimator show that wage flexibility in relation to labor productivity was about 0.09 for Poland and by about 0.14 for Ukraine.

\section{Notes}

1 United Nations Economic Commission for Europe, data base: Labour Force \& Wages (https://w3.unece.org/PXWeb2015/pxweb/en/STAT/STAT__20-ME__3MELF/, access: 2019-12-30).

2 Source: Macrotrends (2019), https://www.macrotrends.net/countries/POL/poland/ gdp-growth-rate, and The World Bank Group, Indicators, (2019).

3 https://bank.gov.ua/markets.

4 The quarrel began in March 2005. The situation returned to normal in January 2006. The next conflict began in October 2007 and lasted until 2009.

5 In 2013, the population of the Crimean Peninsula numbered about 2.4 million people (5.2\% of the population of Ukraine), and about 1.1 million people were employed there (5.3\% of Ukraine's workforce). Similar indicators for the Donbas 


\section{Pawel Dykas et al.}

are 6.6 million inhabitants (14.5\% of the population of Ukraine) and 3.0 million employed (14.6\% of those employed in Ukraine).

6 The decline in labor productivity in the voivodeships of western Poland in 2016 was mainly due to the fact that the number of employed there grew faster than the GDP. In 2016, the GDP in this group of voivodeships increased by $3.2 \%$, while the number of those employed by as much as $12.9 \%$. A similar process took place in the Mazowieckie voivodeship in 2014, when the GDP increased by $4.2 \%$ and the number of employed by $8.8 \%$.

7 In 2015, wages in the voivodeships of central Poland amounted to PLN 3960.16 and western Poland to PLN 3 869.11, and were therefore lower than the wages in the Mazowieckie voivodeship in 2004.

8 Areas with high structural unemployment are also significant parts of the Dolnośląskie and Lubuskie voivodeships and the areas of the former Słupsk voivodeship in the western part of the Pomorskie voivodeship (for more on this topic, see: Misiak, Tokarski 2012 or Majchrowska et al. 2013

9 Government Agriculture Farm.

10 Data on the Autonomous Republic of Crimea and Sevastopol illustrated on Maps 5.4-5.6 (due to Russia's annexation of the Crimean Peninsula in 2014) are average values of the analyzed variables from 2004 to 2013. 